\title{
Evaluating Health Hazards of Harmful Metals in Roadway Dust Particles Finer than $100 \mu \mathrm{m}$
}

\author{
Dongqi Shi, Xinwei Lu*, Qian Wang \\ Department of Environmental Science, School of Geography and Tourism, \\ Shaanxi Normal University, Xi'an, China
}

Received: 1 October 2017

Accepted: 26 November 2017

\begin{abstract}
Pollution degrees and health hazards of harmful metals in roadway dust particles finer than $100 \mu \mathrm{m}$ in various functional areas in Xi'an, China were investigated in our study exploring the impact of land use methods on the environment. X-ray fluorescence spectrometry was used to measure the content of harmful metals, and their pollution degrees were assessed by using the geoaccumulation index and Nemerow synthetic pollution index. The health risks of harmful metals to local residents were judged using the U.S. EPA health risk model. The present study reveals that $\mathrm{Co}, \mathrm{Cr}, \mathrm{Pb}, \mathrm{Cu}$, and $\mathrm{Zn}$ in the samples were 2.1-6.3, 1.9-4.8, 2.1-9.7, 1.1-4.6, and 0.9-13.0 times the corresponding background contents of local soil, respectively. Due to the influence of local land use and the diversity of sources, harmful metals in the various functional areas have different variation characteristics. The assessment results show that $\mathrm{Ni}, \mathrm{Mn}$, and $\mathrm{V}$ were unpolluted, while $\mathrm{Co}, \mathrm{Cr}, \mathrm{Pb}, \mathrm{Cu}$, and $\mathrm{Zn}$ presented pollution in different degrees. The analyzed harmful metals were moderately polluted in park and traffic areas, while in residential and educational areas were heavily polluted. The non-carcinogenic hazards of all measured harmful metals were within the safe range, and the cancer hazards of $\mathrm{Co}, \mathrm{Cr}$, and $\mathrm{Ni}$ were in the acceptable range.
\end{abstract}

Keywords: pollution, health risk assessment, metal, dust, functional area

\section{Introduction}

Environmental pollution is getting worse in many cities, particularly in developing countries. Owing to the influence of human activities, soil, water, and air pollution have become more serious in urban areas [1-2]. Because organic pollutants and harmful metals can easily accumulate in it, dust is often studied as an important environmental medium to evaluate the contamination and health hazards of pollutants [3-6]. The pollutants accumulated in dust can enter the human body through

*e-mail: luxinwei@snnu.edu.cn dermal contact, ingestion, and inhalation [1, 5-6]. So, harmful metals in dust, as a part of pollutants accumulated in dust, are highly concerning to scientists due to their non-degradability, durability, and toxicity [7-10].

Since urban roadway dust is the source and sink of pollutants, content, source, distribution, pollution degree, and environmental risk of harmful metals in urban roadway dust have been investigated during the past decades [1-3, 6-22]. The contamination features of harmful metals in urban roadway dust are closely affected by local anthropogenic activities and land use [20-22]. The findings before show that roadway dust collected from heavy traffic sites and industrial areas often contain elevated anthropogenic metals $[12,20]$. Most works got 
that conclusion mainly through urban roadway dust bulk samples, whereas differently sized dusts have distinct transport modes and diverse environmental effects [8, 23]. Under the traffic stream, pedestrian flow, and wind, dust particles finer than $100 \mu \mathrm{m}$ are more easily re-suspended into the atmosphere [24-25], which makes the particle able to be inhaled and adhere more, and be transported long-distances compared to dust particles bigger than 100 $\mu \mathrm{m}$. Moreover, owing to these particles often containing elevated harmful metals [24-26], the environmental effect and harm of roadway dust particles finer than $100 \mu \mathrm{m}$ are greater than the dust bulk sample [24-25]. Therefore, pollution and environmental risk of harmful metals finer than $100 \mu \mathrm{m}$ roadway dust should be paid more attention.

For efficient urban governance there are different functional areas in one city, and each functional area takes on different land use ways and anthropogenic activities that cause environmental characteristics in different functional areas. On the basis of the aforesaid facts, research was conducted on harmful metals pollution in finer than 100 $\mu \mathrm{m}$ roadway dust from various functional areas in Xi'an, China. Xi'an has experienced rapid industrialization and urbanization in recent decades, leading to harmful metal pollution in roadway dust and urban soil [27-28]. Previous research has indicated that harmful metal contamination was detected in the bulk samples of urban campus dust, street dust, and topsoil from Xi'an [27-31]. Our group had investigated the possible source of harmful metals in finer than $100 \mu \mathrm{m}$ roadway dust from various functional areas of Xi'an [28]. This study is a continuation of our earlier work. On our previous basis, the present work focused on the assessment of pollution degree and health risk of harmful metals in finer than $100 \mu \mathrm{m}$ roadway dust from various functional areas of Xi'an. The results could offer basic information for environmental protection and risk management by urban governments.

\section{Material and Methods}

\section{Background of Study Area}

Xi'an, a famous historical and cultural city, is located in the Guanzhong Basin of Shaanxi Province in northwest China (Fig. 1). Its climate is a temperate continental monsoon climate. The annual average precipitation and temperature of Xi'an are $500-700 \mathrm{~mm}$ and $13-15^{\circ} \mathrm{C}$ [1]. The permanent resident population was more than 8.7 million in 2015. The motor vehicle number was 2,394,100 in 2015. Static wind weather occurs frequently in Xi'an owing to the city being surrounded by mountains, and this may prevent dust from migrating and may influence the local environment [17]. Being the capital city of Shaanxi province, Xi'an is also a center of education, culture,

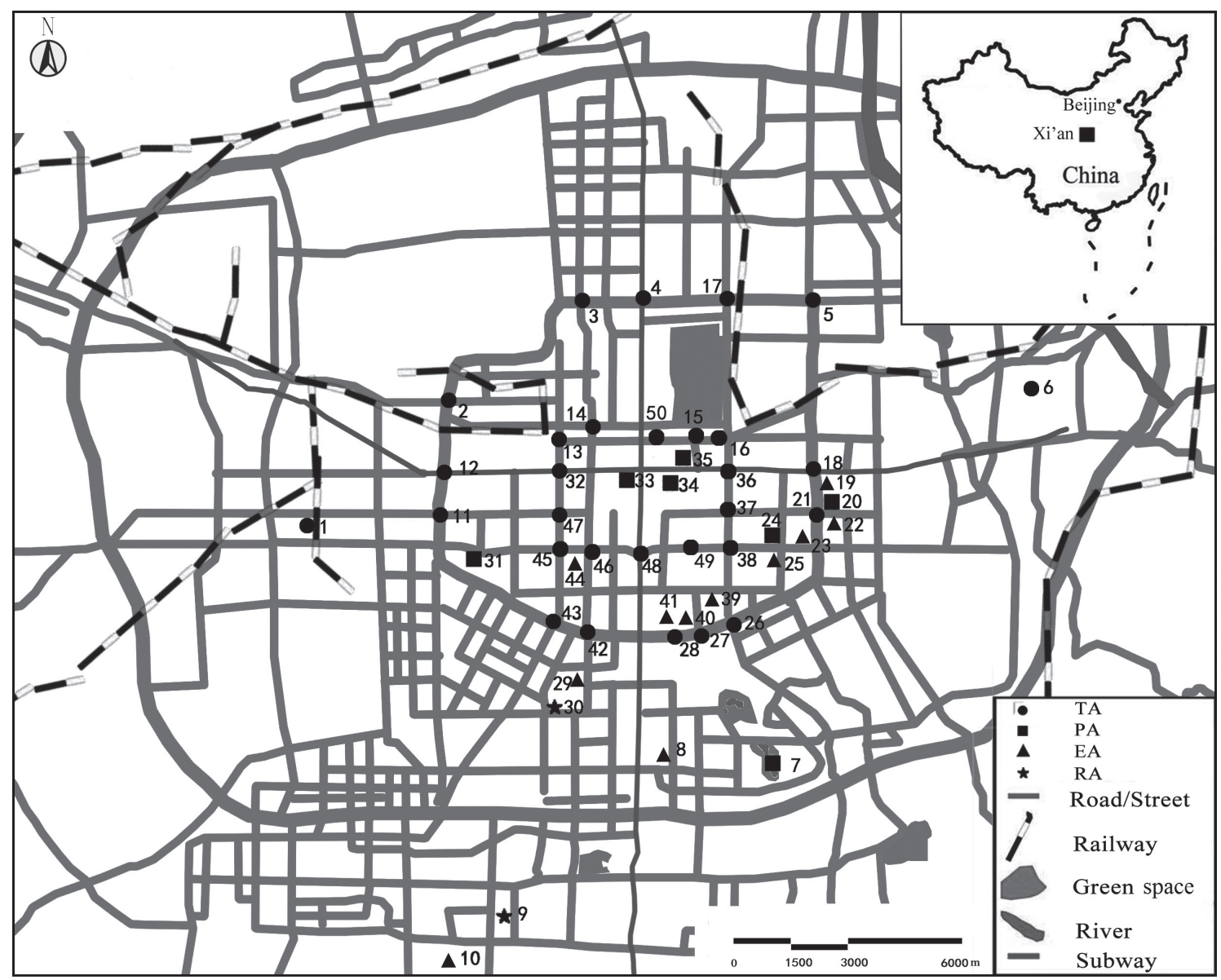

Fig. 1. Study area and sampling locations from 4 various functional areas in Xi'an. 
manufacturing, and high-tech industries in northwestern China.

\section{Sample and Experimental Method}

Ninety-four roadway dust samples were collected from 4 functional areas of Xi'an city: educational area (EA) $(\mathrm{N}=33)$, traffic area (TA) $(\mathrm{N}=30)$, park area (PA) $(\mathrm{N}=21)$, and residential area $(\mathrm{RA})(\mathrm{N}=10)$. Ten universities were selected in the EA: Xi'an Jiaotong University, Northwest University, Shaanxi Normal University (Yanta campus and Chang'an campus), Chang'an University, Xi'an University of Science and Technology, Xi'an Technological University, Xi'an Polytechnic University, Xi'an University of Architecture and Technology, Xi'an Academy of Fine Arts, and Xi'an University of Technology. TA includes eastern and western suburbs, the second ring, and first ring roads. Lianhu park, Geming Park, Fengqing Park, Xincheng Square, Qujiang Park, Xingqing Park, and Changle Park were chosen in the PA. For the RA, two larger residential districts, Ziweihuayuan and Zhihuicheng, were selected. All sampling locations are presented in Fig. 1.

One to five roadway dust samples (about 200-250 g each) were gathered at each sampling location using a brush from a pavement or road in April 2015 [28]. The dust samples were stored in PVC bags and transported to the laboratory. In the laboratory, the samples were airdried under room temperature and then sieved through a $1.0 \mathrm{~mm}$ nylon sieve to screen out impurities and small stones. Then approximately $20 \mathrm{~g}$ of each sample was separated and sieved through a $100 \mu \mathrm{m}$ nylon mesh. The $<100 \mu \mathrm{m}$ dust samples were collected. For determining harmful metal content, the $<100 \mu \mathrm{m}$ dust samples were ground to less than $0.075 \mathrm{~mm}$.

Each milled dust sample was pressed into a $32-\mathrm{mm}$ diameter pellet with boric acid binding for element content determination using $\mathrm{x}$-ray fluorescence spectrometry (XRF). A PANalytical PW2403 XRF apparatus was used in the study to measure the content of the harmful metals $\mathrm{Co}, \mathrm{Cr}, \mathrm{Pb}, \mathrm{Cu}, \mathrm{Zn}, \mathrm{Ni}, \mathrm{Mn}$, and $\mathrm{V}$ in finer than $100 \mu \mathrm{m}$ roadway dust samples from various functional areas of Xi'an [28], owing to these heavy metals being frequently reported to accumulate in urban dust [11-12, 28-32] and the contents of these heavy metals in finer road dusts being generally high [23-26]. The quality control of the experiment was conducted using duplicated samples and standard samples during the measurement [12, 32]. Measurement precision and accuracy were $<5 \%$.

\section{Pollution and Health Risk Assessment of Harmful Metal}

Pollution degrees of $\mathrm{Co}, \mathrm{Cr}, \mathrm{Pb}, \mathrm{Cu}, \mathrm{Zn}, \mathrm{Ni}, \mathrm{Mn}$, and $\mathrm{V}$ in the finer than $100 \mu \mathrm{m}$ roadway dust samples were evaluated using the Nemerow synthetic pollution index $(N S P I)$ and geoaccumulation index $\left(I_{\text {geo }}\right)$, which are widely applied to assess heavy metal contamination in water, soil, sediment, and dust [7, 12, 15, 33-37].
The $I_{\text {geo }}$ and NSPI were respectively used to assess the pollution degree of single metal and the general pollution degree of all metals analyzed in the samples, which are calculated according to the following equations [12, 29]:

$$
\begin{gathered}
I_{g e o}=\log _{2} \frac{C_{i}}{1.5 S_{i}} \\
N S P I=\sqrt{\frac{\left(\frac{C_{i}}{S_{i}}\right)_{\max }^{2}+\left(1 / n \sum_{i=1}^{n} \frac{C_{i}}{S_{i}}\right)^{2}}{2}}
\end{gathered}
$$

...where $S_{i}$ is the background content of harmful metal $i$ in Shaanxi soil [38] and $C_{i}$ is the concentration of harmful metal $i$ in the dust sample. The classifications of pollution degrees of harmful metals in the sample according to $I_{\text {geo }}$ and NSPI value were cited from the literature [12, 29].

The health hazards of harmful metals in finer than $100 \mu \mathrm{m}$ roadway dust to local inhabitants (children and adults) include non-carcinogenic risk and carcinogenic risk, which were assessed using the exposure model of USEPA [39]. All harmful metals analyzed in the samples have non-carcinogenic risk; meanwhile, $\mathrm{Cr}, \mathrm{Co}$, and $\mathrm{Ni}$ also have carcinogenic risk [1]. Inhalation, dermal contact, and ingestion are 3 main exposure routes of harmful metals in finer than $100 \mu \mathrm{m}$ roadway dust to the human body [1, 19,22]. The dose of 3 exposure routes was respectively estimated by the following equations (3)-(5) [39], which were used to assess the non-carcinogenic risk. The lifetime average daily dose $(L A D D)$ (inhalation exposure route for $\mathrm{Cr}, \mathrm{Co}$ and $\mathrm{Ni}$ ) was used to evaluate the cancer risks of $\mathrm{Cr}, \mathrm{Co}$, and $\mathrm{Ni}[4,21,39]$.

$$
\begin{aligned}
& D_{\text {inh }}=C \times \frac{\mathrm{InhR} \times \mathrm{EF} \times \mathrm{ED}}{\mathrm{PEF} \times \mathrm{BW} \times \mathrm{AT}} \\
& D_{\text {ing }}=C \times \frac{\mathrm{IngR} \times \mathrm{EF} \times \mathrm{ED}}{\mathrm{BW} \times \mathrm{AT}} \times 10^{-6} \\
& D_{\text {dermal }}=C \times \frac{\mathrm{SL} \times \mathrm{SA} \times \mathrm{ABS} \times \mathrm{EF} \times \mathrm{ED}}{\mathrm{BW} \times \mathrm{AT}} \times 10^{-6} \\
& L A D D=\frac{C \times \mathrm{EF}}{\mathrm{PEF} \times \mathrm{AT}} \times\left(\frac{\mathrm{InhR}_{\text {child }} \times \mathrm{ED}_{\text {child }}}{\mathrm{BW}_{\text {child }}}+\right. \\
& \left.+\frac{\mathrm{InhR}_{\text {adult }} \times \mathrm{ED}_{\text {adult }}}{B W_{\text {adult }}}\right)
\end{aligned}
$$

...where $C$ is the content $(\mathrm{mg} / \mathrm{kg})$ of harmful metal in finer than $100 \mu \mathrm{m}$ roadway dust (exposure point content). $D_{\text {inh }}, D_{\text {ing }}$, and $D_{\text {dermal }}$ are respectively the dose ( $\mathrm{mg} / \mathrm{kg} /$ day) of inhalation exposure, ingestion exposure and dermal contact exposure. The meanings and values 
of other parameters can be found in the literature $[1,24$, 39]. The doses estimated for each harmful metal and each exposure route are divided by the corresponding reference dose $(\mathrm{mg} / \mathrm{kg} /$ day) to produce a hazard quotient (HQ) (or non-carcinogenic hazard), whereas for carcinogens the dose is multiplied by the corresponding slope factor $\left((\mathrm{mg} / \mathrm{kg} / \mathrm{day})^{-1}\right)$ to yield a level of cancer risk $[1,24]$. The sum of HQ is hazard index (HI). The non-carcinogenic effects may occur when $\mathrm{HI}>1$, and the probability of noncarcinogenic risk tends to increase with the HI increasing [39]. Significant non-carcinogenic risk will not occur when $\mathrm{HI}<1$. Carcinogenic risk is the probability of an individual developing any type of cancer from lifetime exposure to carcinogenic hazards. The acceptable value of carcinogenic risk is in the range of $10^{-6}-10^{-4}$ [39].

\section{Results and Discussion}

\section{Content of Harmful Metal in Finer than $100 \mu \mathrm{m}$ Roadway Dust}

Fig. 2 presents the measurement results of $\mathrm{Co}, \mathrm{Cr}$, $\mathrm{Pb}, \mathrm{Cu}, \mathrm{Zn}, \mathrm{Ni}, \mathrm{Mn}$, and $\mathrm{V}$ contents in finer than $100 \mu \mathrm{m}$ roadway dust samples gathered from 4 functional areas in Xi'an, China. It can be found that the content ranged from 22.6 to $66.7,120.1$ to $300.7,45.5$ to $208.4,22.7$ to $98.3,61.6$ to $898.9,21.9$ to $37.2,281.7$ to 429.7 , and 48.3 to $70.5 \mathrm{mg} / \mathrm{kg}$, with the mean of $34.1,175.3,97.6,48.9$, $164.9,28.3,339.4$ and $55.8 \mathrm{mg} / \mathrm{kg}$ for $\mathrm{Co}, \mathrm{Cr}, \mathrm{Pb}, \mathrm{Cu}, \mathrm{Zn}$, $\mathrm{Ni}, \mathrm{Mn}$, and $\mathrm{V}$, respectively. Compared to the background contents in Shaanxi soil $(62.5,10.6,21.4,21.4,69.4,28.8$, 557 , and $66.9 \mathrm{mg} / \mathrm{kg}$ for $\mathrm{Cr}, \mathrm{Co}, \mathrm{Pb}, \mathrm{Cu}, \mathrm{Zn}, \mathrm{Ni}, \mathrm{Mn}$, and $\mathrm{V}$, respectively) [38], the investigated samples have elevated $\mathrm{Pb}, \mathrm{Cu}, \mathrm{Zn}, \mathrm{Cr}$, and $\mathrm{Co}$, which were respectively 2.1-9.7, 1.1-4.6, 0.9-13.0, 1.9-4.8, and 2.1-6.3 times the corresponding background contents in Shaanxi soil. Their coefficients of variation $(33 \%, 29 \%, 77 \%, 18 \%$ and $31 \%$ for $\mathrm{Pb}, \mathrm{Cu}, \mathrm{Zn}, \mathrm{Cr}$ and $\mathrm{Co}$, respectively) are comparatively larger than $\mathrm{Ni}, \mathrm{Mn}$, and $\mathrm{V}(12 \%, 9 \%$, and $9 \%$ for $\mathrm{Ni}, \mathrm{Mn}$, and $\mathrm{V}$, respectively), demonstrating that the contents of

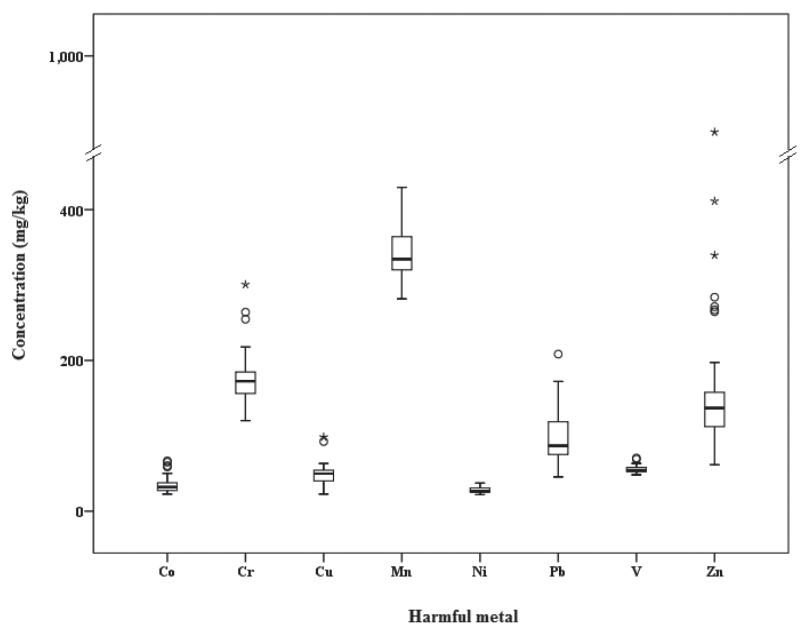

Fig. 2. Content of harmful metals in the samples.
$\mathrm{Pb}, \mathrm{Cu}, \mathrm{Zn}, \mathrm{Cr}$, and $\mathrm{Co}$ in the investigated roadway dusts were affected by local anthropogenic activities.

The investigated harmful metals in finer than $100 \mu \mathrm{m}$ roadway dusts of different functional areas have diverse concentration characters (Fig. 3). The samples gathered from EA, RA, and TA have more toxic metals contents, in particular $\mathrm{Cr}, \mathrm{Pb}, \mathrm{Cu}$, and $\mathrm{Zn}$. The Co contents in the samples of EA, PA, and TA are similar, which are larger than RA. The contents of $\mathrm{Ni}, \mathrm{Mn}$, and $\mathrm{V}$ in the samples gathered from RA and EA are slightly more than the contents in the samples collected from the other 2 functional areas. The concentration disparities of harmful metals measured in the finer than $100 \mu \mathrm{m}$ roadway dust samples from 4 functional areas can be explained by their sources. Our previous work shows that $\mathrm{Cr}, \mathrm{Pb}, \mathrm{Cu}$, and $\mathrm{Zn}$ in the finer than $100 \mu \mathrm{m}$ roadway dust samples from different functional areas of Xi'an primarily came from traffic sources, and Co mainly originated from construction sources such as the construction dusts of Co-containing building materials (alloy, coating material, paint, and pigment), while $\mathrm{V}, \mathrm{Mn}$, and $\mathrm{Ni}$ are primarily derived from natural sources (local soil) [28]. More toxic metals contents (particularly $\mathrm{Cr}, \mathrm{Pb}, \mathrm{Cu}$, and $\mathrm{Zn}$ ) in the samples from EA and RA implicate the fact that the number of motor vehicles in EA and RA appear to have blown out in the last decade, whereas the vehicle number in PA is limited owing to entrance restriction. Higher $\mathrm{Zn}$ and $\mathrm{Pb}$ contents were found in RA and EA (Fig. 3), which are probably due to the dense buildings impeding the dispersion of vehicle emissions in these areas [28]. There are many building sites in PA, EA, and TA owing to ancient building renovation, campus construction, and road widening, while there is no construction activity presently in the investigated RA. As a main source of Co, more construction dusts produced in those building sites has resulted in more Co generated in PA, EA, and TA than in RA.

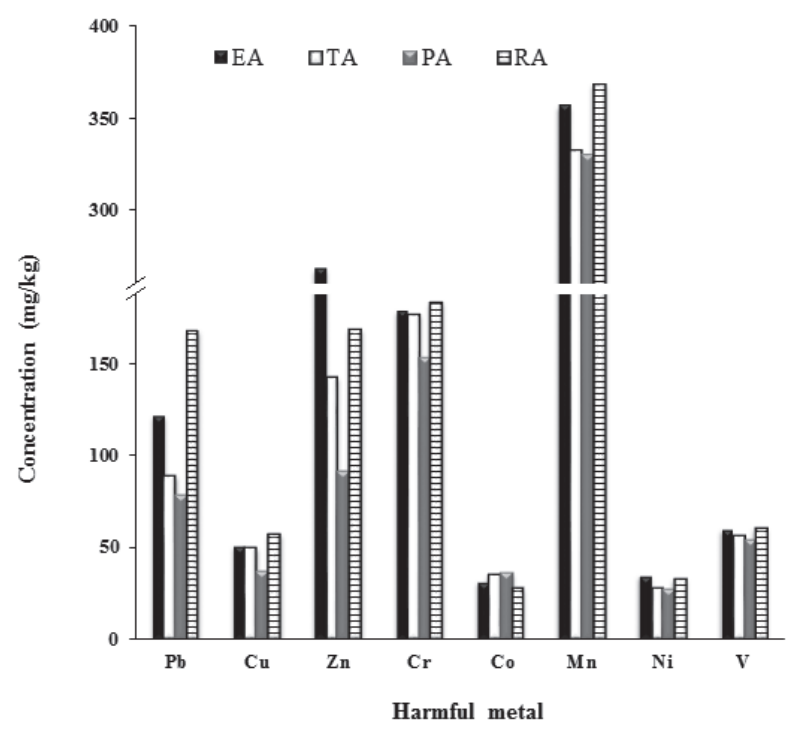

Fig. 3. Harmful metals in the samples from 4 various functional areas of Xi'an. 
Table 1. Comparison of harmful metals in finer than $100 \mu \mathrm{m}$ roadway dusts from Xi'an and other cities $(\mathrm{mg} / \mathrm{kg})$.

\begin{tabular}{|c|c|c|c|c|c|c|c|c|c|}
\hline City/Country & $\mathrm{Pb}$ & $\mathrm{Cu}$ & $\mathrm{Zn}$ & $\mathrm{Cr}$ & $\mathrm{Co}$ & $\mathrm{Ni}$ & $\mathrm{V}$ & $\mathrm{Mn}$ & Reference \\
\hline Xi'an/China & 97.6 & 48.9 & 164.9 & 175.3 & 34.1 & 28.3 & 55.8 & 339.4 & Present study \\
\hline Xining/China & 52.9 & 40.8 & 108.9 & 576.8 & 50.0 & 22.6 & 57.1 & 408.7 & {$[24]$} \\
\hline Baotou/China & 59.9 & 31.5 & 77.5 & 247.8 & 56.2 & 26.1 & 82.2 & 566.3 & {$[25]$} \\
\hline Huludao/China & 533.2 & 264.4 & 5271 & na & na & na & na & na & {$[40]$} \\
\hline Luanda/Angola & 351.3 & 41.78 & 316.6 & 25.65 & 2.9 & 10 & 20 & 258 & {$[41]$} \\
\hline
\end{tabular}

na: not available

Table 1 presents a comparison of harmful metal concentrations in the finer than $100 \mu \mathrm{m}$ roadway dust samples from Xi'an and some other cities reported in the literature [24-25, 40-41]. It can be found that the mean concentrations of harmful metals are different in the finer than $100 \mu \mathrm{m}$ roadway dusts from the cities compared. The concentration levels of harmful metals in finer than $100 \mu \mathrm{m}$ roadway dusts were affected by the local natural environment and human activities, e.g., climate, topography, industrial activities, vehicle exhaust, fossil fuel combustion, population size, and developing stages of the city [24-25]. The existing research indicated that the content differences of harmful metals in finer than $100 \mu \mathrm{m}$ roadway dusts may be related to their sources and the intensity and method of anthropogenic activities [24]. It is reported that the motorized vehicle numbers of Xi'an, Xining, and Baotou in 2015 are respectively 2.4 million, 0.3 million, and 0.46 million [24-25, 28]. Meanwhile there does not exist a zinc smelting industry in Xi'an, Xining, and Baotou. In the study, the mean concentrations of $\mathrm{Pb}$, $\mathrm{Cu}$, and $\mathrm{Zn}$ in the finer than $100 \mu \mathrm{m}$ roadway dust samples from Xi'an is higher than the mean concentrations in the samples collected from Xining and Baotou, which revealed the fact that vehicle emissions is a key factor affecting the concentration of $\mathrm{Pb}, \mathrm{Cu}$, and $\mathrm{Zn}$ in those 3 cities. The concentrations of $\mathrm{Pb}, \mathrm{Cu}$, and $\mathrm{Zn}$ in Huludao, and $\mathrm{Pb}$ and $\mathrm{Zn}$ in Luanda are significantly higher than their corresponding concentrations in Xi'an, which is closely related to the industrial activities in these two cities. Huludao is an industrial city with zinc smelting and Luanda is an industrialized city concerned with oil refining, cement production, and zinc smelting [40-41]. The mean concentrations of $\mathrm{Cr}, \mathrm{Co}$, and $\mathrm{Mn}$ in the dust samples from Xi'an are lower than those from Xining and Baotou, and higher than those from Luanda. The $\mathrm{Ni}$ concentration in Xi'an is higher than in Xining and Luanda, and is close to Baotou. The mean concentration of $\mathrm{Mn}$ in finer than $100 \mu \mathrm{m}$ roadway dusts from Xi'an is higher than Luanda, and lower than Xining and Baotou. $\mathrm{Co}$ and $\mathrm{Cr}$ can be found in stainless and alloy steels [11, 24]. Higher $\mathrm{Co}$ and $\mathrm{Cr}$ concentrations in finer than $100 \mu \mathrm{m}$ roadway from Baotou and Xining were mainly influenced by local industrial activities (e.g., steel mill), steel mill being the pillaring industry in Baotou and Xining [2425]. The diversity of $\mathrm{Mn}, \mathrm{Ni}$, and $\mathrm{V}$ among the compared cities is mainly caused by local soil characteristics, owing to these 3 metals in the compared cities originating from natural sources [24-25, 28, 41].

\section{Pollution Degree of Harmful Metals}

Table 2 shows the calculated results of $I_{\text {geo }}$ and NSPI for the harmful metals determined in the finer than $100 \mu \mathrm{m}$ roadway dust samples from various functional areas in Xi'an. It can be noticed that the $I_{\text {geo }}$ values of Ni, $\mathrm{Mn}$, and $\mathrm{V}$ in all samples are $<0$, showing that there was no $\mathrm{Mn}, \mathrm{Ni}$, and $\mathrm{V}$ pollution in the finer than $100 \mu \mathrm{m}$ roadway dust samples. The $I_{\text {geo }}$ values ranged from 0.50 to $2.70,-0.50$ to $1.61,-0.76$ to $3.11,0.36$ to 1.68 , and 0.51 to 2.07 , with an average of $1.53,0.54,0.45,0.88$,

Table 2. The $I_{g e o}$ and NSPI of harmful metals in finer than $100 \mu \mathrm{m}$ roadway dusts from 4 various functional areas in Xi'an.

\begin{tabular}{|c|c|c|c|c|c|c|c|c|c|}
\hline \multirow{2}{*}{ Area } & \multicolumn{8}{|c|}{$I_{g e o}$} & \multirow{2}{*}{ NSPI } \\
\hline & $\mathrm{Pb}$ & $\mathrm{Cu}$ & $\mathrm{Zn}$ & $\mathrm{Cr}$ & $\mathrm{Co}$ & $\mathrm{Ni}$ & V & $\mathrm{Mn}$ & \\
\hline EA & 1.91 & 0.62 & 1.10 & 0.91 & 0.92 & -0.42 & -0.76 & -1.23 & 3.44 \\
\hline $\mathrm{TA}$ & 1.41 & 0.61 & 0.36 & 0.91 & 1.10 & -0.70 & -0.90 & -1.33 & 2.47 \\
\hline $\mathrm{PA}$ & 1.23 & 0.11 & -0.26 & 0.71 & 1.07 & -0.68 & -0.84 & -1.34 & 2.35 \\
\hline RA & 2.34 & 0.82 & 0.84 & 0.96 & 0.79 & -0.41 & -0.73 & -1.18 & 4.14 \\
\hline Minimum & 0.50 & -0.50 & -0.76 & 0.36 & 0.51 & -0.98 & -1.05 & -1.57 & 1.44 \\
\hline Maximum & 2.70 & 1.61 & 3.11 & 1.68 & 2.07 & -0.22 & -0.51 & -0.96 & 6.78 \\
\hline Arithmetic mean & 1.53 & 0.54 & 0.45 & 0.88 & 1.04 & -0.62 & -0.85 & -1.31 & 2.73 \\
\hline
\end{tabular}


Table 3. Hazard quotients, hazard indices, and cancer risks of harmful metals in finer than $100 \mu \mathrm{m}$ roadway dust from educational and traffic areas of Xi'an.

\begin{tabular}{|c|c|c|c|c|c|c|c|c|}
\hline Element & $\mathrm{Pb}$ & $\mathrm{Cu}$ & $\mathrm{Zn}$ & $\mathrm{Cr}$ & Co & $\mathrm{Mn}$ & $\mathrm{Ni}$ & V \\
\hline \multicolumn{9}{|c|}{ Educational area } \\
\hline \multicolumn{9}{|c|}{ Children } \\
\hline $\mathrm{HQ}_{\text {ing }}$ & $2.29 \mathrm{E}-01$ & $8.37 \mathrm{E}-03$ & $5.86 \mathrm{E}-03$ & $3.93 \mathrm{E}-01$ & $1.03 \mathrm{E}-02$ & $5.10 \mathrm{E}-02$ & $1.14 \mathrm{E}-02$ & $5.60 \mathrm{E}-02$ \\
\hline$H Q_{\text {inh }}$ & $6.40 \mathrm{E}-06$ & $2.34 \mathrm{E}-07$ & $1.64 \mathrm{E}-07$ & $1.16 \mathrm{E}-03$ & $1.01 \mathrm{E}-03$ & $4.60 \mathrm{E}-03$ & $3.12 \mathrm{E}-07$ & $1.57 \mathrm{E}-06$ \\
\hline $\mathrm{HQ}_{\text {dermal }}$ & $4.28 \mathrm{E}-03$ & 7.81E-05 & $8.21 \mathrm{E}-05$ & $5.50 \mathrm{E}-02$ & 3.61E-05 & $3.57 \mathrm{E}-03$ & 1.19E-04 & $1.57 \mathrm{E}-02$ \\
\hline $\mathrm{HI}$ & 2.34E-01 & $8.45 \mathrm{E}-03$ & $5.95 \mathrm{E}-03$ & 4.49E-01 & $1.14 \mathrm{E}-02$ & 5.92E-02 & $1.16 \mathrm{E}-02$ & 7.17E-02 \\
\hline \multicolumn{9}{|c|}{ Adults } \\
\hline $\mathrm{HQ}_{\text {ing }}$ & $2.46 \mathrm{E}-02$ & $8.96 \mathrm{E}-04$ & $6.28 \mathrm{E}-04$ & $4.21 \mathrm{E}-02$ & $1.11 \mathrm{E}-03$ & $5.47 \mathrm{E}-03$ & $1.23 \mathrm{E}-03$ & $6.00 \mathrm{E}-03$ \\
\hline $\mathrm{HQ}_{\text {inh }}$ & $3.59 \mathrm{E}-06$ & $1.31 \mathrm{E}-07$ & $9.24 \mathrm{E}-08$ & $6.49 \mathrm{E}-04$ & $5.70 \mathrm{E}-04$ & $2.59 \mathrm{E}-03$ & $1.75 \mathrm{E}-07$ & $8.82 \mathrm{E}-07$ \\
\hline $\mathrm{HQ}_{\text {dermal }}$ & $6.54 \mathrm{E}-04$ & $1.19 \mathrm{E}-05$ & $1.25 \mathrm{E}-05$ & $8.40 \mathrm{E}-03$ & 5.52E-06 & $5.45 \mathrm{E}-04$ & $1.81 \mathrm{E}-05$ & $2.39 \mathrm{E}-03$ \\
\hline $\mathrm{HI}$ & $2.52 \mathrm{E}-02$ & $9.09 \mathrm{E}-04$ & $6.41 \mathrm{E}-04$ & $5.11 \mathrm{E}-02$ & $1.68 \mathrm{E}-03$ & 8.60E-03 & $1.24 \mathrm{E}-03$ & 8.39E-03 \\
\hline Cancer risk & & & & $3.86 \mathrm{E}-09$ & $1.58 \mathrm{E}-08$ & & $1.50 \mathrm{E}-09$ & \\
\hline \multicolumn{9}{|c|}{ Traffic area } \\
\hline \multicolumn{9}{|c|}{ Children } \\
\hline $\mathrm{HQ}_{\text {ing }}$ & $1.66 \mathrm{E}-01$ & $8.17 \mathrm{E}-03$ & $3.12 \mathrm{E}-03$ & $3.88 \mathrm{E}-01$ & $1.15 \mathrm{E}-02$ & $4.76 \mathrm{E}-02$ & 8.94E-03 & $5.28 \mathrm{E}-02$ \\
\hline$H Q_{\text {inh }}$ & 4.64E-06 & $2.28 \mathrm{E}-07$ & $8.74 \mathrm{E}-08$ & $1.14 \mathrm{E}-03$ & $1.13 \mathrm{E}-03$ & 4.30E-03 & $2.44 \mathrm{E}-07$ & $1.48 \mathrm{E}-06$ \\
\hline $\mathrm{HQ}_{\text {dermal }}$ & $3.11 \mathrm{E}-03$ & $7.63 \mathrm{E}-05$ & $4.36 \mathrm{E}-05$ & $5.43 \mathrm{E}-02$ & 4.04E-05 & $3.33 \mathrm{E}-03$ & $9.27 \mathrm{E}-05$ & $1.48 \mathrm{E}-02$ \\
\hline HI & $1.70 \mathrm{E}-01$ & $8.25 \mathrm{E}-03$ & $3.16 \mathrm{E}-03$ & 4.44E-01 & $1.27 \mathrm{E}-02$ & $5.52 \mathrm{E}-02$ & $9.04 \mathrm{E}-03$ & $6.76 \mathrm{E}-02$ \\
\hline \multicolumn{9}{|c|}{ Adults } \\
\hline $\mathrm{HQ}_{\text {ing }}$ & $1.78 \mathrm{E}-02$ & $8.75 \mathrm{E}-04$ & $3.34 \mathrm{E}-04$ & $4.16 \mathrm{E}-02$ & $1.24 \mathrm{E}-03$ & $5.10 \mathrm{E}-03$ & $9.58 \mathrm{E}-04$ & $5.66 \mathrm{E}-03$ \\
\hline $\mathrm{HQ}_{\mathrm{inh}}$ & 2.61E-06 & $1.28 \mathrm{E}-07$ & 4.91E-08 & $6.42 \mathrm{E}-04$ & $6.37 \mathrm{E}-04$ & $2.41 \mathrm{E}-03$ & $1.37 \mathrm{E}-07$ & $8.32 \mathrm{E}-07$ \\
\hline $\mathrm{HQ}_{\text {dermal }}$ & 4.74E-04 & $1.16 \mathrm{E}-05$ & $6.66 \mathrm{E}-06$ & $8.30 \mathrm{E}-03$ & $6.17 \mathrm{E}-06$ & 5.09E-04 & $1.42 \mathrm{E}-05$ & $2.26 \mathrm{E}-03$ \\
\hline $\mathrm{HI}$ & $1.83 \mathrm{E}-02$ & 8.87E-04 & $3.41 \mathrm{E}-04$ & $5.05 \mathrm{E}-02$ & $1.88 \mathrm{E}-03$ & 8.02E-03 & $9.72 \mathrm{E}-04$ & 7.91E-03 \\
\hline Cancer risk & & & & 3.81E-09 & 3.81E-09 & & $1.17 \mathrm{E}-09$ & \\
\hline
\end{tabular}

and 1.04 for $\mathrm{Pb}, \mathrm{Cu}, \mathrm{Zn}, \mathrm{Cr}$, and $\mathrm{Co}$, respectively, which indicates that $\mathrm{Cr}, \mathrm{Zn}$, and $\mathrm{Cu}$ were unpolluted to moderately polluted, while $\mathrm{Pb}$ and $\mathrm{Co}$ were moderately polluted in the samples on the whole. The pollution degree range and maximum pollution degrees of $\mathrm{Cr}, \mathrm{Co}, \mathrm{Pb}, \mathrm{Cu}$, and $\mathrm{Zn}$ in the samples are different. $\mathrm{Zn}$ has the largest pollution degree range and its maximum pollution degree is heavily polluted $\left(I_{\text {geo }}=3.11\right)$. $\mathrm{Pb}$ and $\mathrm{Co}$ have similar pollution degree ranges and their maximum pollution degrees were moderately to heavily polluted $\left(I_{\text {geo }}=2.70\right.$ for $\mathrm{Pb}$ and $I_{\text {geo }}=2.07$ for $\mathrm{Co}$ ). The maximum pollution degrees of $\mathrm{Cu}$ and $\mathrm{Cr}$ were moderately polluted $\left(I_{g e o}=1.61\right.$ for $\mathrm{Cu}$ and $I_{\text {geo }}=1.68$ for $\mathrm{Cr}$ ). The pollution degrees of harmful metals were different in the samples collected from 4 functional areas of Xi'an (Table 2). $\mathrm{Pb}$ in RA was moderately to heavily polluted, while the other 3 functional areas were moderately polluted. $\mathrm{Cu}$ and $\mathrm{Cr}$ in 4 functional areas were all unpolluted to moderately polluted. $\mathrm{Zn}$ had the large pollution difference in 4 functional areas. Co in EA and RA presented unpolluted to moderately polluted, while
TA and PA were moderately polluted. $\mathrm{Mn}, \mathrm{Ni}$, and $\mathrm{V}$ in all functional areas were unpolluted.

The NSPI values of harmful metals in finer than $100 \mu \mathrm{m}$ roadway dusts from 4 functional areas in Xi'an were in the range 1.44 to 6.78 with an average of 2.73 (Table 2), showing slightly polluted to heavily polluted. The comprehensive pollution degree of harmful metals in the samples from EA $(N S P I=3.44)$ and RA $(N S P I=4.14)$ indicated that the 2 areas were heavily polluted, while the degrees in the samples from TA $(N S P I=2.47)$ and PA $(N S P I=2.35)$ showed that TA and PA were moderately polluted. EA and RA are densely populated areas, hence the heavy pollution of harmful metals in these 2 areas should be noted.

\section{Health Hazards of Harmful Metals}

Tables 3 and 4 show the calculated results of hazard quotient (HQ) values for each exposure pathway, hazard index (HI), and cancer risk of harmful metals analyzed 
Table 4. Hazard quotients, hazard indices, and cancer risks of harmful metals in finer than $100 \mu \mathrm{m}$ roadway dust from park and residential areas of Xi'an.

\begin{tabular}{|c|c|c|c|c|c|c|c|c|}
\hline Element & $\mathrm{Pb}$ & $\mathrm{Cu}$ & $\mathrm{Zn}$ & $\mathrm{Cr}$ & Co & $\mathrm{Mn}$ & $\mathrm{Ni}$ & V \\
\hline \multicolumn{9}{|c|}{ Park area } \\
\hline \multicolumn{9}{|c|}{ Children } \\
\hline $\mathrm{HQ}_{\text {ing }}$ & $1.47 \mathrm{E}-01$ & $5.98 \mathrm{E}-03$ & $2.00 \mathrm{E}-03$ & 3.36E-01 & $1.17 \mathrm{E}-02$ & 4.72E-02 & 8.81E-03 & $5.07 \mathrm{E}-02$ \\
\hline $\mathrm{HQ}_{\text {inh }}$ & 4.09E-06 & $1.67 \mathrm{E}-07$ & $5.61 \mathrm{E}-08$ & $9.89 \mathrm{E}-04$ & $1.15 \mathrm{E}-03$ & $4.26 \mathrm{E}-03$ & $2.40 \mathrm{E}-07$ & $1.42 \mathrm{E}-06$ \\
\hline $\mathrm{HQ}_{\text {derm }}$ & $2.74 \mathrm{E}-03$ & $5.58 \mathrm{E}-05$ & $2.80 \mathrm{E}-05$ & $4.71 \mathrm{E}-02$ & 4.10E-05 & $3.31 \mathrm{E}-03$ & $9.14 \mathrm{E}-05$ & $1.42 \mathrm{E}-02$ \\
\hline HI & $1.49 \mathrm{E}-01$ & $6.04 \mathrm{E}-03$ & $2.03 \mathrm{E}-03$ & $3.84 \mathrm{E}-01$ & $1.29 \mathrm{E}-02$ & $5.48 \mathrm{E}-02$ & $8.90 \mathrm{E}-03$ & $6.49 \mathrm{E}-02$ \\
\hline \multicolumn{9}{|c|}{ Adults } \\
\hline $\mathrm{HQ}_{\text {ing }}$ & $1.57 \mathrm{E}-02$ & $6.41 \mathrm{E}-04$ & $2.14 \mathrm{E}-04$ & $3.60 \mathrm{E}-02$ & $1.25 \mathrm{E}-03$ & $5.06 \mathrm{E}-03$ & $9.44 \mathrm{E}-04$ & $5.43 \mathrm{E}-03$ \\
\hline $\mathrm{HQ}_{\text {inh }}$ & $2.30 \mathrm{E}-06$ & $9.38 \mathrm{E}-08$ & $3.15 \mathrm{E}-08$ & $5.56 \mathrm{E}-04$ & $6.46 \mathrm{E}-04$ & $2.39 \mathrm{E}-03$ & $1.35 \mathrm{E}-07$ & 7.99E-07 \\
\hline $\mathrm{HQ}_{\text {derm }}$ & $4.18 \mathrm{E}-04$ & $8.53 \mathrm{E}-06$ & 4.27E-06 & 7.19E-03 & $6.25 \mathrm{E}-06$ & $5.05 \mathrm{E}-04$ & $1.40 \mathrm{E}-05$ & $2.17 \mathrm{E}-03$ \\
\hline $\mathrm{HI}$ & $1.61 \mathrm{E}-02$ & $6.50 \mathrm{E}-04$ & $2.18 \mathrm{E}-04$ & $4.38 \mathrm{E}-02$ & $1.91 \mathrm{E}-03$ & $7.96 \mathrm{E}-03$ & $9.58 \mathrm{E}-04$ & $7.60 \mathrm{E}-03$ \\
\hline Cancer risk & & & & 3.30E-09 & $1.79 \mathrm{E}-08$ & & $1.15 \mathrm{E}-09$ & \\
\hline \multicolumn{9}{|c|}{ Residential area } \\
\hline \multicolumn{9}{|c|}{ Children } \\
\hline $\mathrm{HQ}_{\text {ing }}$ & $3.15 \mathrm{E}-01$ & $9.37 \mathrm{E}-03$ & 4.36E-03 & 4.02E-01 & $9.14 \mathrm{E}-03$ & $5.27 \mathrm{E}-02$ & $1.07 \mathrm{E}-02$ & $5.67 \mathrm{E}-02$ \\
\hline $\mathrm{HQ}_{\text {inh }}$ & $8.78 \mathrm{E}-06$ & 2.62E-07 & $1.22 \mathrm{E}-07$ & $1.18 \mathrm{E}-03$ & $8.98 \mathrm{E}-04$ & $4.76 \mathrm{E}-03$ & $2.92 \mathrm{E}-07$ & $1.59 \mathrm{E}-06$ \\
\hline $\mathrm{HQ}_{\text {derm }}$ & 5.87E-03 & $8.75 \mathrm{E}-05$ & $6.10 \mathrm{E}-05$ & $5.62 \mathrm{E}-02$ & $3.20 \mathrm{E}-05$ & $3.69 \mathrm{E}-03$ & $1.11 \mathrm{E}-04$ & $1.59 \mathrm{E}-02$ \\
\hline HI & $3.21 \mathrm{E}-01$ & $9.46 \mathrm{E}-03$ & $4.42 \mathrm{E}-03$ & $4.59 \mathrm{E}-01$ & $1.01 \mathrm{E}-03$ & $6.12 \mathrm{E}-02$ & $1.08 \mathrm{E}-02$ & $7.26 \mathrm{E}-02$ \\
\hline \multicolumn{9}{|c|}{ Adults } \\
\hline $\mathrm{HQ}_{\text {ing }}$ & $3.37 \mathrm{E}-02$ & $1.00 \mathrm{E}-03$ & 4.67E-04 & $4.30 \mathrm{E}-02$ & $9.79 \mathrm{E}-04$ & $5.65 \mathrm{E}-03$ & $1.15 \mathrm{E}-03$ & $6.08 \mathrm{E}-03$ \\
\hline $\mathrm{HQ}_{\mathrm{inh}}$ & 4.93E-06 & $1.47 \mathrm{E}-07$ & $6.86 \mathrm{E}-08$ & $6.64 \mathrm{E}-04$ & $5.04 \mathrm{E}-04$ & $2.67 \mathrm{E}-03$ & $1.64 \mathrm{E}-07$ & $8.94 \mathrm{E}-07$ \\
\hline $\mathrm{HQ}_{\text {derm }}$ & 8.97E-04 & $1.34 \mathrm{E}-05$ & $9.31 \mathrm{E}-06$ & $8.58 \mathrm{E}-03$ & 4.88E-06 & $5.63 \mathrm{E}-04$ & $1.70 \mathrm{E}-05$ & $2.43 \mathrm{E}-03$ \\
\hline HI & $3.46 \mathrm{E}-02$ & $1.02 \mathrm{E}-03$ & 4.76E-04 & $5.23 \mathrm{E}-02$ & $1.49 \mathrm{E}-03$ & $8.88 \mathrm{E}-03$ & $1.17 \mathrm{E}-03$ & $8.51 \mathrm{E}-03$ \\
\hline Cancer risk & & & & 3.94E-09 & $1.40 \mathrm{E}-08$ & & $1.40 \mathrm{E}-09$ & \\
\hline
\end{tabular}

in finer than $100 \mu \mathrm{m}$ roadway dusts from 4 functional areas in Xi'an, China. We can find that ingestion is the major exposure pathway for all investigated harmful metals to adults and children in 4 functional areas (Tables 3 and 4$)$.

The $\mathrm{HQ}_{\text {dermal }}$ values of $\mathrm{Cr}, \mathrm{Pb}, \mathrm{Zn}, \mathrm{Cu}, \mathrm{Ni}$, and $\mathrm{V}$ are higher than their $\mathrm{HQ}_{\text {inh }}$ values, while the $\mathrm{HQ}_{\text {dermal }}$ values of $\mathrm{Co}$ and $\mathrm{Mn}$ are lower than their $\mathrm{HQ}_{\text {inh }}$ values in the samples studied, indicating that the exposure routes of non-carcinogenic hazards of $\mathrm{Cr}, \mathrm{Pb}, \mathrm{Zn}, \mathrm{Cu}, \mathrm{Ni}$, and $\mathrm{V}$ are mainly through ingestion and dermal absorption, while the non-carcinogenic risks of $\mathrm{Mn}$ and $\mathrm{Co}$ are mainly through ingestion and inhalation. The values of HQs and HI of each analyzed harmful metal to children in all functional areas are larger than those values to adults, demonstrating that children are more allergic to harmful metals and have more potential non-carcinogenic hazards than adults. The non-carcinogenic hazards of all harmful metals in finer than $100 \mu \mathrm{m}$ roadway dusts from 4 functional areas to adults and children are within the safe level $(\mathrm{HI}<1)$ suggested by the USEPA [39], which indicates little health risk to adults and children owing to harmful metals exposure in finer than $100 \mu \mathrm{m}$ roadway dusts.

The carcinogenic risks of $\mathrm{Co}, \mathrm{Cr}$, and $\mathrm{Ni}$ in finer than $100 \mu \mathrm{m}$ roadway dusts from four various functional areas in Xi'an increase in the order $\mathrm{Ni}<\mathrm{Cr}<\mathrm{Co}$ (Tables 3 and 4). They are less than the present acceptable value $\left(10^{-6}-10^{-4}\right)[1,8,31]$, demonstrating that these metals in finer than $100 \mu \mathrm{m}$ roadway dusts from various functional areas in Xi'an are unlikely to cause carcinogenesis to local residents.

\section{Conclusions}

The contents of the harmful metals $\mathrm{Co}, \mathrm{Cr}, \mathrm{Pb}, \mathrm{Cu}$, $\mathrm{Zn}, \mathrm{Ni}, \mathrm{Mn}$, and $\mathrm{V}$ in finer than $100 \mu \mathrm{m}$ roadway dusts from various functional areas in Xi'an have determined using XRF in the present work. Their pollution degrees 
were assessed by the geoaccumulation index and Nemero synthesis pollution index, and their health hazards to local inhabitants were analyzed by using the U.S. EPA health risk model. The mean contents of $\mathrm{Co}, \mathrm{Cr}, \mathrm{Pb}, \mathrm{Cu}$, and $\mathrm{Zn}$ in the samples were significantly larger than the background contents of Shaanxi soil, whereas the mean contents of $\mathrm{Ni}$, $\mathrm{Mn}$, and $\mathrm{V}$ in the samples were less than their background contents of Shaanxi soil. The analyzed harmful metals presented different variation characteristics in the samples gathered from 4 functional areas in Xi'an. The pollution assessment results of the geoaccumulation index indicate that $\mathrm{Ni}, \mathrm{Mn}$, and $\mathrm{V}$ were unpolluted, $\mathrm{Cr}, \mathrm{Cu}$, and $\mathrm{Zn}$ were unpolluted to moderately polluted, while $\mathrm{Pb}$ and $\mathrm{Co}$ were moderately polluted in finer than $100 \mu \mathrm{m}$ roadway dust from the study area. The comprehensive pollution degree of the investigated harmful metals presented as heavily polluted in the samples from the educational and residential areas, while the traffic and park areas appeared to be moderately polluted.

Generally, we think the urban surface dusts collected from the traffic and industrial areas have more severe heavy metal pollution than the dusts collected from the residential, educational, and park areas due to the influences of heavy traffic and industrial activities. That knowledge was mainly derived from the content of heavy metals in the dust bulk sample. The contamination assessment results of harmful metals in this work indicate that the finer particles in urban surface dusts from different functional areas have different spatial pollution characteristics. The findings of this work are different from the usual estimations, which remind researchers and managers that they should pay attention to harmful metals in the finer dust particles, and the environmental quality of residential, educational, and park areas in other cities and regions.

The assessment results of health risk indicate that ingestion is the major exposure pathway for harmful metals to adults and children. All harmful metals studied in the finer than $100 \mu \mathrm{m}$ roadway dust samples cannot cause non-carcinogenic hazards and cancer risk to local residents according to the currently acceptable range. The conclusions of this work were based on the concentrations of the harmful metals $\mathrm{Co}, \mathrm{Cr}, \mathrm{Pb}, \mathrm{Cu}, \mathrm{Zn}, \mathrm{Ni}, \mathrm{Mn}$, and $\mathrm{V}$ in finer than $100 \mu \mathrm{m}$ roadway dusts. As is known, the other harmful metals such as $\mathrm{Cd}, \mathrm{Hg}$, and As have greater toxicity and health hazards, so the pollution levels and health risks of $\mathrm{As}, \mathrm{Cd}$, and $\mathrm{Hg}$ in dusts will be determined in our future work. Meanwhile, the impacts of mineral type and content, as well as the particle size composition and morphology of the finer than $100 \mu \mathrm{m}$ roadway dusts on harmful metal contamination and environmental risk will also be further investigated in our follow-up study.

\section{Acknowledgements}

This research was supported by the National Natural Science Foundation of China with grant No. 41271510 and the Fundamental Research Funds for the
Central Universities with grant Nos. GK201601009 and 2017TS027. The authors acknowledge Yuxin Li, Ying Liu, and $\mathrm{Na}$ Yin for assisting with the collection, preparation, and measurement of dust samples. We also thank Editorin-Chief Professor Jerzy Radecki, Executive Editor Professor Hanna Radecka, and anonymous reviewers for their insightful suggestions and critical reviews of the manuscript.

\section{References}

1. LU X.W., ZHANG X.L., LI L.Y., CHEN H. Assessment of metals pollution and health risk in dust from nursery schools in Xi'an, China. Environmental Research 128, 27, 2014.

2. TANG Z.W., CHAI M., CHENG J.L., JIN J., YANG Y.F., NIE Z.Q., HUANG Q.F., LI Y.H. Contamination and health risk of heavy metals in street dust from a coal-mining city in eastern China. Ecotoxicology and Environmental Safety 138, 83, 2017.

3. SHI G.T., CHEN Z.L., BI C.J., WANG L., TENG J.Y., LI Y.S., XU S.Y. A comparative study of health risk of potential metals in urban and suburban road dust in the most populated city of China. Atmospheric Environment 45, 764, 2011.

4. KURT-KARAKUS P.B. Determination of heavy metals in indoor dust from Istanbul, Turkey: Estimation of the health risk. Environment International 50, 47, 2012.

5. WANG L.J. WANG L., TAO W.D., SMARDON R.C., SHI X.M., LU X.W. Characteristics, sources, and health risk of polycyclic aromatic hydrocarbons in urban surface dust: a case study of the city of Xi'an in Northwest China. Environmental Science and Pollution Research 23, 13389, 2016.

6. SOLTANI N., KESHAVARZI B., MOORE F., TAVAKOL T., LAHIJANZADEH A.R., JAAFARZADEH N., KERMANI M. Ecological and human health hazards of heavy metals and polycyclic aromatic hydrocarbons (PAHs) in road dust of Isfahan metropolis, Iran. Science of the Total Environment 505, 712, 2015.

7. YANG Z.P., GE H.K., LU W.X., LONG Y.Q. Assessment of heavy metals contamination in near-surface dust. Polish Journal of Environmental Studies 24, 1817, 2015.

8. FANG F.M., Li Y.B., LIN Y.S., XU M.L. Grain-size distribution and chemical speciation of heavy metals in Chinese street dust. Polish Journal of Environmental Studies 26, 1501, 2017.

9. ACOSTA J.A., GABARRÓN M., FAZ A., MARTÍNEZMARTÍNEZ S., ZORNOZA R., AROCENA J.M. Influence of population density on the concentration and speciation of metals in the soil and street dust from urban areas. Chemosphere 134, 328, 2015.

10. CHRISTOFORIDIS A., STAMATIS N. Heavy metal contamination in street dust and roadside soil along the major national road in Kavala's region, Greece. Geoderma 151, 257, 2009.

11. LU X.W., WANG L.J., LI L.Y., LEI K., HUANG L., KANG D. Multivariate statistical analysis of heavy metals in street dust of Baoji, NW China. Journal of Hazardous Materials 173, 744, 2010.

12. LU X.W., PAN H.Y., WANG Y.W. Pollution evaluation and source analysis of heavy metal in roadway dust from a resource-typed industrial city in Northwest China. Atmospheric Pollution Research 8, 587, 2017. 
13. SAEEDI M., LI L.Y., SALMANZADEH M. Heavy metals and polycyclic aromatic hydrocarbons: pollution and ecological risk assessment in street dust of Tehran. Journal of Hazardous Materials 227-228, 9, 2012.

14. ORDÓÑEZ A., ÁlVAREZ R., DE MIGUEL E., CHARLESWORTH S. Spatial and temporal variations of trace element distribution in soils and street dust of an industrial town in NW Spain: 15 years of study. Science of the Total Environment 524-525, 93, 2015.

15. TANG R.L., MA K.M., ZHANG Y.X., MAO Q.Z. The spatial characteristics and pollution levels of metals in urban street dust of Beijing, China. Applied Geochemistry 35, 88, 2013.

16. LI Z.G., FENG X.B., LI G.H., BI X.Y., ZHU J.M., QIN H.B., DAI Z.H., LIU Q.H., SUN G.Y. Distribution, sources and pollution status of 17 trace metal/metalloids in the street dust of a heavily industrialized city of central China. Environmental Pollution 182, 408, 2013.

17. ZHANG C.X., QIAO Q.Q., APPEL E., HUANG B.C. Discriminating sources of anthropogenic heavy metals in urban street dusts using magnetic and chemical methods. Journal of Geochemical Exploration 119-120, 60, 2012.

18. HUSSAIN K., RAHMAN M., PRAKASH A., HOQUE R.R. Street dust bound PAHs, carbon and heavy metals in Guwahati city-Seasonality, toxicity and sources. Sustainable Cities and Society 19, 17, 2015.

19. KESHAVARZI B., TAZARVI Z., RAJABZADEH M., NAJMEDDIN A. Chemical speciation, human health risk assessment and pollution level of selected heavy metals in urban street dust of Shiraz, Iran. Atmospheric Environment $119,1,2015$.

20. TRUJILLO-GONZÁLEZ J.M., TORRES-MORA M.A., KEESSTRA S., BREVIK E.C., JIMÉNEZ-BALLESTA R. Heavy metal accumulation related to pollution density in road dust samples taken from urban sites under different land uses. Science of the Total Environment 553, 636, 2016.

21. LI H.H., CHEN L.J., YU L., GUO Z.B., SHAN C.Q., LIN J.Q., GU Y.G., YANG Y.X., SHAO J.R., ZHU X.M., CHENG Z. Pollution characteristics and risk assessment of human exposure to oral bioaccessibility of heavy metals via urban street dusts from different functional areas in Chengdu, China. Science of the Total Environment 586, 1076, 2017.

22. WEI X., GAO B., WANG P., ZHOU H.D., LU J. Pollution characteristics and health risk assessment of heavy metals in street dusts from different functional areas in Beijing, China. Ecotoxicology and Environmental Safety 112, 186, 2015.

23. LI H.Y., SHI A.B., ZHANG X.R. Particle size distribution and characteristics of heavy metals in road-deposited sediments from Beijing Olympic Park. Journal of Environmental Science 32, 228, 2015.

24. XU X., LU X.W., HAN X.F., ZHAO N. Ecological and health risk assessment of metal in resuspended particles of urban street dust from an industrial city in China. Current Science 108, 72, 2015.

25. ZHAO N., LU X.W., CHAO S.G., XU X. Multivariate statistical analysis of heavy metals in less than $100 \mu \mathrm{m}$ particles of street dust from Xining, China. Environmental Earth Sciences 73, 2319, 2015.

26. ZHAO N., LU X.W., CHAO S.G. Level and contamination assessment of environmentally sensitive elements in smaller than $100 \mu \mathrm{m}$ street dust particles from Xining, China. International Journal of Environmental Research and Public Health 11, 2536, 2014.

27. CHEN X.D., LU X.W., YANG G. Sources identification of heavy metals in urban topsoil from inside the Xi'an Second Ringroad, NW China using multivariate statistical methods. Catena 98, 73, 2012.

28. WANG Q., LU X.W., PAN H.Y. Analysis of heavy metals in the re-suspended road dusts from different functional areas in Xi'an, China. Environmental Science and Pollution Research 23, 19838, 2016.

29. CHEN H., LU X.W., CHANG Y.Y., XUE W.Z. Heavy metal contamination in dust from kindergartens and elementary schools in Xi'an, China. Environmental Earth Sciences 71, 2710, 2014

30. CHEN H., LU X.W., LI L.Y., GAO T.N., CHANG Y.Y. Metal contamination in campus dust of Xi'an, China: A study based on multivariate statistics and spatial distribution. Science of the Total Environment 484, $27,2014$.

31. CHEN H., LU X.W., LI L.Y. Spatial distribution and risk assessment of metals in dust based on samples from nursery and primary schools of Xi'an, China. Atmospheric Environment 88, 172, 2014.

32. PAN H., LU X.W., LEI K. A comprehensive analysis of heavy metals in urban road dust of Xi'an, China: contamination, source apportionment and spatial distribution. Science of the Total Environment 609, 1361, 2017.

33. CHEN L.S., CAI Q.X., XU S.W., LIU X.B., CHEN S.J. Distribution characteristics, pollution assessment, and source identification of heavy metals in sediments of wetland lakes. Polish Journal of Environmental Studies 24, $1525,2015$.

34. KHALILOVA H., MAMMADOV V. Assessing the anthropogenic impact on heavy metal pollution of soils and sediments in urban areas of Azerbaijan's oil industrial region. Polish Journal of Environmental Studies 25, 159, 2016.

35. GEVORGYAN G.A., MAMYAN A.S., HAMBARYAN L.R., KHUDAVERDYAN S.K., VASEASHTA A. Environmental risk assessment of heavy metal pollution in Armenian River ecosystems: case study of Lake Sevan and Debed River catchment basins. Polish Journal of Environmental Studies 25, 2387, 2016.

36. LI Y.K., ZHOU X.J., WANG X., LIU Q.C., ZHU P.F., ZHANG L.C., SUN C.Y. Distribution and ecological risk assessment of heavy metals in sediments in Chinese collapsed lakes. Polish Journal of Environmental Studies 26, $181,2017$.

37. OKORO H.K., ORIMOLADE B.O., ADEBAYO G.B., AKANDE B.A., XIMBA B.J., NGILA J.C. An assessment of heavy metals contents in the soil around a cement factory in Ewekoro, Nigeria using pollution indices. Polish Journal of Environmental Studies 26, 221, 2017.

38. CNEMC (China National Environmental Monitoring Center). The Background Values of Elements in Chinese Soils. Environmental Science Press of China, Beijing, China, 1990 [In Chinese].

39. USEPA. Supplement Guidance for Developing Soil Screening Levels for Superfund Sites. OSWER 9355.424. Office of Emergency and Remedial Response, U.S. Environmental Protection Agency, Washington, DC 20460, 2002.

40. ZHENG N., LIU J.S., WANG Q.C., LIANG Z.Z. Health risk assessment of heavy metal exposure to street dust in zinc smelting district, Northeast of China. Science of the Total Environment 408, 726, 2010.

41. FERREIRA-BAPTISTA L., DE MIGUEL E. Geochemistry and risk assessment of street dust in Luanda, Angola: a tropical urban environment. Atmospheric Environment 39, 4501, 2005. 
